\title{
飽和度の高い砂層における間隙水圧の伝ぱ PROPAGATION OF PORE WATER PRESSURE IN SAND LAYER OF HIGH DEGREE OF SATURATION
}

\author{
井上 令 作* \\ By Reisaku INOUE
}

\section{1. まえがき}

完全に飽和している砂層内にお括間隚水圧の 伝ぱ 䟩，主に砂層骨格の弹性的な伸縮によっておこると考え られる。しかし, 不飽和状態の砂層における伝ぱでは, 砂層骨格の伸縮性のほかに間嚐内に含まれている気泡の 特性, すなわち, 気泡の圧縮性, 圧力変化によっておこ る気泡の水に対する溶解, 放出の現象, また気泡の表面 張力の問題などを考慮しなければならず，その伝ぱの様 相も複雑になってくる。

本報告注，不飽和状態の砂層に㧍ける間隙水圧の伝ぱ について考察したものであるが，特に，飽和度が高い砂 層において，周期的変動水圧が作用した場合，気泡のも つ圧縮性による間隚永圧の伝ぱを中心に述べた。間隙水 圧の伝ぱに関する基本式を誘導するにあたっては, 気泡 がもっているこれらの特性を正確に式の中に組み入れる ならば，式は複雑な非線型となるために，式の適用範囲 を限定して，現象と大きくかけ離れない程度に線型化し 簡明な式で表現するよう心がけた。

基本式を確かめるために実験を行ったが，実験装置と して動的透水試験器（仮称）と加圧装置を製作した。こ の装置は間隙水圧を周期的に加圧するために，空気圧で 正弦的に加圧できるようにし，広い範囲の周波数で実験 できるようにした。間偿水圧の計測のために半導体ゲー ジを使用した微少水圧計を製作したが，この水圧計は増 幅を必要としないために, 多点での微少水圧の計測を簡 単に行うことができた。この結果, 計算值と実測值は, 高、飽和度（実験では 87 97\% の範囲）の砂層ではよ く一致し, 式の妥当性を確かめることができた。

\section{2. 間吵水圧の伝ぱに関係する要素}

不飽和状態の砂層において間隚水圧の伝ぱに関倸する
おもな要素として，砂層の飽和度，気泡および砂層骨格 の圧縮率，透水係数などが考えられる。

いま, 気泡, 水, 砂粒子で構成されている砂層内にお いて, 一定容積 $(V)$ の中で, 間隚水圧の変化に応じて 変わる構成図を開いた系で図示すると Fig. 1 のように
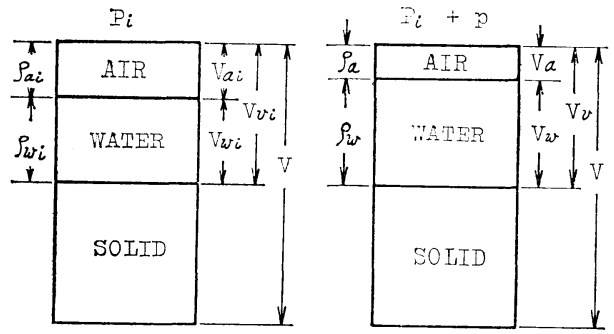

Fig. 1 Composition of Porous Media

なる。図の左側は初期間隚水圧 $P_{i}$ (絶対圧力) のもと における状態を示し，右側は初期間隊水圧 $P_{i}$ の上に $p$ （ゲージ圧力）が作用し，間隚水圧が $P_{i}+p$ になったと きの状態を示す。この構成図にしたがって気泡量，有効 間隚率，飽和度などを表わすと次のようにかける。

$$
\begin{aligned}
& n_{i}=V_{v i} / V, n=V_{v} / V \text { (間偿率) } \\
& n_{a i}=V_{a i} / V, n_{a}=V_{a} / V \text { （全容積に㸚する気泡含 } \\
& \text { 有率) } \\
& a_{c i}=V_{a i} / V_{v i}, a_{c}=V_{a} / V_{v} \text { （間潆量に対方気泡 } \\
& \text { 含有率) } \\
& n_{w i}=V_{w i} / V, n_{w}=V_{w} / V \text { (有効間潆㳯) } \\
& S_{r i}=V_{w i} / V_{v i}, S_{r}=V_{w} / V_{v} \text { （飽和度） }
\end{aligned}
$$

上述の各要素を考察するにあたり，間隙内に含まれる 水の質量の間隚水圧 $p$ による変化を調べてみる。いま, 単位容積の砂層内の水の質量を $M=\rho_{w} n_{w}$ で表わし，こ れを $p$ で微分すると,

$$
\begin{aligned}
\frac{d M}{d p} & =\rho_{w} \frac{d n_{w}}{d p}+n_{w} \frac{d \rho_{w}}{d p} \\
& =\rho_{w}\left(\frac{d n}{d p}-\frac{d n_{a}}{d p}\right)+n_{w} \frac{d \rho_{w}}{d p}
\end{aligned}
$$


となる。上式で， $d n / d p$ は砂層骨格の伸縮性によるも ので, $d n_{a} / d p$ および $d \rho_{v v} / d p$ はそれぞれ気泡と水の圧 縮性によるものである。

ここで, 気泡の圧縮率 (一般に, 圧縮率は $-\frac{1}{V_{a}} \frac{d V_{a}}{d p}$ とすべきで脑るが，以下の式の誘導を簡単にするため に, $-\frac{1}{V_{a i}} \frac{d V_{a}}{d p}$ で表わし, 以後この值を気泡の 圧縮 率と呼ぶ）を,

$$
K_{a}=-\frac{1}{V_{a i}} \frac{d V_{a}}{d p}=-\frac{1}{n_{a i}} \frac{d n_{a}}{d p}
$$

砂層骨格の圧縮率を，

$$
K_{s}=\frac{1}{V} \frac{d V_{v}}{d p}=\frac{d n}{d p}
$$

水の圧縮率を,

$$
K_{w}=\frac{1}{\rho_{w}} \frac{d \rho_{w}}{d p}
$$

とおくならば，式（1）は次のようにかける。

$$
\frac{d M}{d p}=\rho_{w}\left(K_{s}+n_{a i} K_{a}+n_{w} K_{w}\right)
$$

\section{（1）気泡の圧縮率}

a）間隙水圧 $p$ が一定圧の場合

気泡の圧縮率を決定するさいには，ボイル・ゲールサ ックの法則, ヘンリーの法則, 気泡の表面張力などを考 慮しなければならない。いま，気泡の体積変化は等温変 化と仮定し, 気泡内の圧力と間隚水圧は等しい（表面張 力を無視した場合）とする。また，気泡は砂粒子にしっ かりと付着していて水の流動に応じて移動しないと仮定 する（この仮定は 4.（2）b）に述べる実験結果からも 推測できる)。以上の仮定をもとに，初期間隚水圧 $P_{i}$ （絶対圧力）のもとに，一定間隚水圧 $p$ （ゲージ圧力） が作用し，間隚水圧が $P_{i}+p$ になった場合，間隙水圧 と気泡量の関係は，ボイルの法則とヘンリーの法則を適 用すると次のようにかける。

$$
P_{i}\left(V_{a i}+H V_{w i}\right)=\left(P_{i}+p\right)\left(V_{a}+H V_{w}\right)
$$

ここで, $H$ はヘンリ一の定数で, $20^{\circ} \mathrm{C}$ における值は 0.02 である。また，上式の右辺の $V_{w}$ は閉じた系で考 える場合には, 間幥水圧の変化に応じて系内一対する水 の流入，流出がないために $V_{w i}$ となるが，このように 開いた系で考える場合には，系内へ対する水の流入，流 出があるので, 間隚水圧 $P_{i}+p$ のもとに抢ける水の容 積 $V_{w}$ を用いた。上式で, $V_{w i}=V_{v i}-V_{a i}, V_{w}=V_{v}$ - $V_{a}$ とかけるが, $V_{v i}$ が $V_{v}$ になる変化は開いた系 で考える場合には，砂層骨格の伸縮性による変化である から，その変化がヘンリーの法則におよぼす影響は非常 に小さい。 $V_{v} \fallingdotseq V_{v i}$ として上式をかきかえると，次の 式（3）のように書きなおすことができる。

$$
P_{i}\left\{n_{a i}+H\left(n_{i}-n_{a i}\right)\right\}=\left(P_{i}+p\right)\left\{n_{a}+H\left(n_{i}-n_{a}\right)\right\}
$$

この式より，気泡含有率 $n_{a}$ と気泡の圧縮率 $K_{a}$ は次 のようにかける。

$$
\left.\begin{array}{l}
n_{a}=\frac{1}{P_{i}+p}\left(n_{a i} P_{i}-\frac{H}{1-H} n_{i} p\right) \\
\frac{d n_{a}}{d p}=-\frac{P_{i}}{\left(P_{i}+p\right)^{2}}\left(n_{a i}+\frac{H}{1-H} n_{i}\right) \\
K_{a}=-\frac{1}{n_{a i}} \frac{d n_{a}}{d p}
\end{array}\right\}
$$

式（4）は気泡の表面張力を 無視した場合の式である が，実際には，表面張力のために気泡内の圧力はまわり の間隚水圧よりも高くなっている。いま，気泡の形状を 球形と仮定して, 間淂水圧 $P_{i}$ のもとでの気泡の半径を $r_{i}, P_{i}+p$ のもとでの半径を $r$ とすると, 気泡内の圧 力は， $T_{s}$ を表面張力とすると， それぞれ， $2 T_{s} / r_{i}$, $2 T_{s} / r$ だけまわりの間偿水圧よりも高い $\left(20^{\circ} \mathrm{C}\right.$ で $T_{s}=$ $0.074 \mathrm{~g} / \mathrm{cm}$ )。

次に表面張力の影響を調べるにあたり，最も簡単に考 えて, 一定容積の砂層の中に $N$ 個の同一径の気泡が含ま れていると仮定すると，気泡量は次のようになる。

$$
\begin{gathered}
V_{a i}=\frac{4}{3} \pi r_{i}{ }^{3} N, \quad V_{a}=\frac{4}{3} \pi r^{3} N \\
\text { この } 2 \text { つの式より } 1 / r=1 / r_{i}\left(n_{a i} / n_{a}\right)^{1 / 3} \quad \text { で, } \\
\frac{2 T_{s}}{r}=\frac{2 T_{s}}{r_{i}}\left(\frac{n_{a i}}{n_{a}}\right)^{1 / 3}
\end{gathered}
$$

となるから，表面張力を考虑した場合の間炒水圧と気泡 量の関係は，式（3）をもとにすると,

$$
\begin{aligned}
& \left(P_{i}+\frac{2 T_{s}}{r_{i}}\right)\left\{n_{a i}+H\left(n_{i}-n_{a i}\right)\right\} \\
& =\left\{P_{i}+p+\frac{2 T_{s}}{r_{i}}\left(\frac{n_{a i}}{n_{a}}\right)^{1 / 3}\right\}\left\{n_{a}+H\left(n_{i}-n_{a}\right)\right\}
\end{aligned}
$$

となるから，気泡含有率と圧縮率は次のようになる。

$$
\left.\begin{array}{c}
\left(P_{i}+p\right)=\frac{n_{a i}+H\left(n_{i}-n_{a i}\right)}{n_{a}+H\left(n_{i}-n_{a}\right)}\left(P_{i}+\frac{2 T_{s}}{r_{i}}\right) \\
-\frac{2 T_{s}}{r_{i}}\left(\frac{n_{a i}}{n_{a}}\right)^{1 / 3} \\
\frac{d n_{a}}{d p}=-\left[\frac{(1-H)\left\{n_{a i}+H\left(n_{i}-n_{a i}\right)\right\}}{\left\{n_{a}+H\left(n_{i}-n_{a}\right)\right\}^{2}}\right. \\
\left.\cdot\left(P_{i}+\frac{2 T_{s}}{r_{i}}\right)-\frac{2 T_{s}}{3 r_{i}} \frac{1}{n_{a}}\left(\frac{n_{a i}}{n_{a}}\right)^{1 / 3}\right]^{-1} \\
K_{a}=-\frac{1}{n_{a i}} \frac{d n_{a}}{d p}
\end{array}\right\}
$$

上式の第 1 の式と第 2 の式はともに右辺に $n_{a}$ を含ん だ形の式となっているが，第 1 の式から 数值計算で $n_{a}$ を求め, その值を第 2 , 第 3 の式に代入して, $d n_{a} / d p$, $K_{a}$ を計算することができる。

b）間隚水圧 $p$ が周期的に変動する場合

a) で述べたことは, 間偿水圧 $p$ が時間により変動し 
ない一定圧の場合の, 気泡の圧縮率についてであり, 気 泡の水に対する溶解, 放出による気泡量の時閒的変化に ついていっさい考慮しなかった。しかし， $p$ が時間的に 変化する場合には，この現象について考察する必要があ る。

さて，間隚内に存在する気泡が水中へ溶解する時間 は，大水量中に存在する気泡の溶解時間に比較して，は るかに大き(20,3)。文献 3）には，砂層の間隚内の気泡 が間隚水に溶解する時間に関してくわしく報告されてい る。この論文の実験式を用いて溶解時間を試算してみ る。たとえば，初期飽和度 $S_{r i}=80 \%$ の砂層に一定間 隚水圧 $p=1 \mathrm{~kg} / \mathrm{cm}^{2}$ が作用した場合，最初，ボイルの 法則でほとんど瞬間的に $S_{r}=90 \%$ になる。その後，へ ンリーの法則でだんだんと水中に溶解していくが，この $S_{r}=90 \%$ が $90.2 \%$ になるのに 6.5 分, $90.4 \%$ で 241 分, $91 \%$ で $2.9 \times 10^{4}$ 分となる。このように飽和度を少 し変化さすだけでも非常に多くの時間が必要である。一 方，気泡の放出の場合にも同程度の時間が必要之考える 之, 変動間隚水圧 $p$ の周期が比較的短、場合には, ヘン リーの法則を考慮しないで，気泡量や圧縮率を算定して もさしつかえない。しかし周期が非常に長い場合には気 泡の水に対する溶解，放出による気泡量の時間的変化を 考虑して，圧縮率を定めなければならないと思われる。

以上の理由により， $p$ が周期的に変動する間腺水圧 で，その周期が比較的短かく，ヘンリーの法則を無視で きる場合には，式（5）で $H=0$ とおいた式で，次のよ うにかくことができる。

$$
\left.\begin{array}{l}
\left(P_{i}+p\right)=\frac{n_{a i}}{n_{a}}\left(P_{i}+\frac{2 T_{s}}{r_{i}}\right)-\frac{2 T_{s}}{r_{i}}\left(\frac{n_{a i}}{n_{a}}\right)^{1 / 3} \\
\frac{d n_{a}}{d p}=-\left\{\frac{n_{a i}}{n_{a}^{2}}\left(P_{i}+\frac{2 T_{s}}{r_{i}}\right)-\frac{2 T_{s}}{3 r_{i}} \frac{1}{n_{a}}\right. \\
\left.\quad\left(\frac{n_{a i}}{n_{a}}\right)^{1 / 3}\right\}^{-1} \\
K_{a}=-\frac{1}{n_{a i}} \frac{d n_{a}}{d p}
\end{array}\right\}
$$

気泡の表面張力が圧縮率におよぼす影響は, 気泡の径 が大きくなるにしたがって小さくなるから，表面張力を 無視できる場合には，式（6）より次のようにかける。

$$
\left.\begin{array}{l}
n_{a}=\frac{P_{i}}{P_{i}+p} n_{a i} \\
K_{a}=-\frac{1}{n_{a i}} \frac{d n_{a}}{d p}=\frac{P_{i}}{\left(P_{i}+p\right)^{2}}
\end{array}\right\}
$$

Fig. 2 は，初期間偿水圧 $P_{i}$ のもとに抢ける気泡の 直径 $D_{i}$ に対する:気泡の圧縮率 $K_{a}$ の変化を, 表面張 力を考慮した場合と無視した場合，すなわち，式 (6) と 式 (7) を比較し， $p$ の值に応じて 示したものである。 一例として, $P_{i}=1$ 気圧の場合を図示した。特別な場合

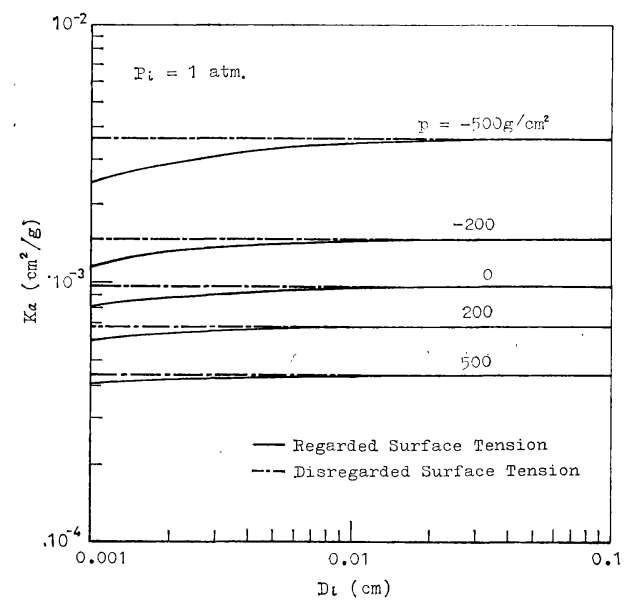

Fig. 2 Influence of Surface Tension for Compressibility of Air Bubbles

をのぞき， $P_{i}$ を大気圧以上と考えるならば， $P_{i}$ が大き いほど，同じ $D_{i}$ に対する表面張力の影響は小さくなる から， $P_{i}$ が大気圧の場合にその影響は最も大きい。そ のために, 気泡の表面張力の影響は, $p$ がよほど大きく ないかぎり, 初期間隙水圧 $P_{i}$ のときの気泡の直径 $D_{i}$ が約 $0.1 \mathrm{~mm}$ 以上では，ほとんどないと考えてよい。し かし, 式 (6)，(7) は, 気泡は全部同一径と仮定し誘導 したもので，実際の場合の気泡の分布状態とは異なる が，Fig. 2 は一応のめやすにはなると思われる。な お，表面張力は $T_{s}=0.074 \mathrm{~g} / \mathrm{cm}$ とし計算した。

\section{（2）砂層骨格の圧縮率}

砂層が弾性平衡の状態にあるならば，間隙水圧の増減 にともない，その間嚐量は弾性的に増減し間隚水圧は伝 ぱする。砂層骨格の圧縮率は前述のように $K_{s}=d n / d p$ であらわすことができるが，一般に $K_{s}$ は定数としてと りあつかわれている場合が多く, 弾性透水層の理論を用 いた海岸地下水の伝ぱに関する研究でも, 定数として計

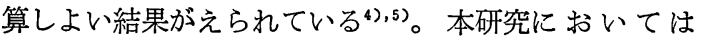
5. (1) で詳述するように，実験砂の $K_{s}$ を間偿水圧の 伝ぱの状態を観察することにより実験的に考察したが， 定数として表わすことはできなかった。しかし， $K_{s}$ を 定数として，実測值とだいたい一致するような $K_{s}$ を求 めると，文献 4)，5）などに使用されている $K_{s}$ と一致 した (Fig. 11 参照)。

\section{（3）透水係数}

間隚水圧の伝ぱに関係する大きな要素として透水係数 がある。閒隚内に気泡が含まれていると，水が自由に流 れらる有効間偿率が小さくなり透水倸数は減少する。ま た間隙水圧の增減にともない，気泡量は変化するので, 
有効間隚率は変化し，透水倸数も間隚水圧の関数となり 変化する。

一方，完全飽和状態における砂の透水係数は間隚率に よって定まり $n^{3} /(1-n)^{2}$ にだいたい比例することが知 られている。不飽和状態の砂層においては，気泡により 水の流通面積が減少するから， $n$ のかわりに有効間隚率 $n_{w}$ を用い $c$ を比例定数として透水係数を表わすと，

$$
k=\frac{c n_{w}^{3}}{\left(1-n_{w}\right)^{2}}
$$

となる。

Fig. 3 は式（8）の関係を調べるために，大気圧中で 行った実験であり，図面の記号には大気圧中の值として

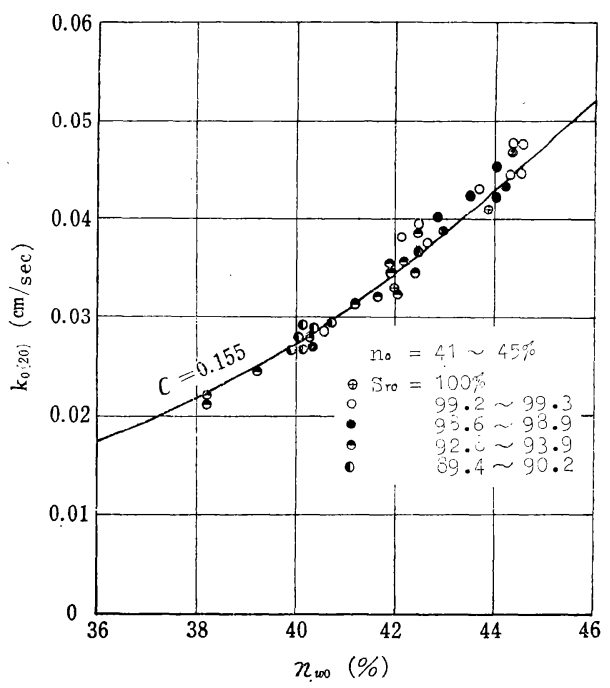

Fig. 3 Relationship between Permeability and Effective Porosity

Suffixに0をつけてある。実験は後述する方法により試 料工の砂を用いて， $n_{0}, n_{a 0}$ をかえて行った 透水試験の 結果である。横軸に $n_{w 0}$ を，たて軸に水温 $20^{\circ} \mathrm{C}$ に補正 した透水係数 $k_{0(20)}$ をとりプロットすると，式 (8) の 関係をほぼ満足している。しかしこの結果は，あくまで も飽和度が高い場合にだけ適用でき，飽和度が低くなる と式（8）は成立しなくなると考えられる。

式（8）は大気圧中では成立することがわかったが， 初期間吵水圧 $P_{i}$ のもとでも成立すると考元ると, その 場合の透水係数は, $k_{i}=c n_{w i}{ }^{3} /\left(1-n_{w i}\right)^{2}$ とかける。この 考えをもら一歩進めて，周期的に間隚水圧が変化する場 合に適用すると， $k$ は周期的に変動する間幥水圧 $p$ に 応じて時々刻々変化すると考える。この場合の気泡含有 率 $n_{a}$ は式 (7) のようにかける。また，開いた系で考 える場合の間幥率の変化は, 砂層骨格の圧縮率だけに関 係し，その変化は非常に小さいので，圧縮率が透水係数 におよぼす影響を無視すると， $n \fallingdotseq n_{i}$ となり，有効間隙
率は $n_{w}=n-n_{a} \doteqdot n_{i}-n_{a}$ とかける。この式の $n_{a}$ に式 （7）を代入すると， $n_{w}$ は次のように表わすことができ る。

$$
n_{w}=\frac{P_{i} n_{w i}+p n_{i}}{P_{i}+p}
$$

また, 式 (9) を式（8）に代入すると，透水係数は $p$ の関数として,

$$
k=\frac{c\left(P_{i} n_{w i}+p n_{i}\right)^{3}}{\left(P_{i}+p\right)\left\{P_{i}\left(1-n_{w i}\right)+p\left(1-n_{i}\right)\right\}^{2}} \cdots \cdots
$$

とかける。上式で，飽和度が高い場合には，pに対する $k$ の変化は小さく，pが大きい変動間淂水圧でなけれ ば，近似的に初期間吵水圧 $P_{i}$ のむとに扔ける $k_{i}$ を用 、れば，透水係数は定数としてとりあつかうことができ る。

\section{3. 間吵水圧の伝ぱの基本式}

不飽和の状態にある砂層の単位体積要素をしめる水の 質量は $M=\rho_{w} n_{w}$ であり， $M$ の間隙水圧 $p$ による变化 率は式 (2) で示される。水の圧縮率は気泡や 砂層の骨 格の圧縮率に比べ非常に小さいので, これを無視し, 比 重は大気圧下にお污る值 $\rho_{w_{0}}$ を用いると式 (2) は， $d M / d p=\rho_{w_{0}}\left(K_{s}+n_{a i} K_{a}\right)$ となり， $M$ の時間 $t$ による 変化率は,

$$
\frac{\partial M}{\partial t}=\rho_{w 0}\left(K_{s}+n_{a i} K_{a}\right) \frac{\partial p}{\partial t}
$$

となり，連続の方程式は， $x, y, z$ 方向の流量流速を $u$, $v, w$ とすると次のようにかける。

$$
\frac{\partial u}{\partial x}+\frac{\partial v}{\partial y}+\frac{\partial w}{\partial z}=-\left(K_{s}+n_{a i} K_{a}\right) \frac{\partial p}{\partial t}
$$

一方，運動方程式は Navier-Stokes の式で速度の 2 乗の項を省略した式が，定常流の場合には Darcy の法 則に帰するものとした誘導法6),7) を用い，間隙率 $n$ のか. わりに有効間隙率 $n_{w}$ を用いて導くと，

$$
\left.\begin{array}{l}
\frac{1}{n_{w} g} \frac{\partial u}{\partial t}=-\frac{1}{\rho_{w_{0}} g} \frac{\partial p}{\partial x}-\frac{u}{k} \\
\frac{1}{n_{w} g} \frac{\partial v}{\partial t}=-\frac{1}{\rho_{w_{0}} g} \frac{\partial p}{\partial y}-\frac{v}{k} \\
\frac{1}{n_{w} g} \frac{\partial w}{\partial t}=-1-\frac{1}{\rho_{w_{0}} g} \frac{\partial p}{\partial z}-\frac{w}{k}
\end{array}\right\}
$$

となる。式（11）と式（12）から基本式を誘導するにあ たり， $p$ が周期的に変動する間隚水圧である場合には， 気泡の圧縮率 $K_{a}$ は，表面張力の影響を無視すると， 式 (7) のようになり $p$ の関数となる。しかし， $p$ (ゲー 汇圧力）が $P_{i}$ (絶対圧力) に比較して小さい場合には, $K_{a} \fallingdotseq 1 / P_{i}$ とかけるから $K_{a}$ を定数としてとりあつかう ことができる。また。砂層骨格の圧縮率 $K_{s}$ は 5.（1) 
で述べるように皦密には定数ではないが，平均值的に見 ると定数で表わすことができる。一方，式 (12) の $n_{w}$ とkも式 (9)，(10）の上うにpの関数となるが，飽和 度が滈く，乙か子，P方 $P_{i}$ に比べ大きくない場合に は, $n_{w}, k$ の変化量は小さいから, $n_{w}, k$ のかわりに初 期間隚水圧 $P_{i}$ のもとに㧍ける值 $n_{t u i}, k_{i}$ を用いるこ とができる。以上のような操作を行い，式 (11) と式 （12）上り間偿水圧の伝ぱに関する線型の式老誘導する と次に示す式となる。

$$
\frac{\partial^{2} p}{\partial t^{2}}+2 \kappa \frac{\partial p}{\partial t}=C^{2}\left(\frac{\partial^{2} p}{\partial x^{2}}+\frac{\partial^{2} p}{\partial y^{2}}+\frac{\partial^{2} p}{\partial z^{2}}\right)
$$

ここで,

$$
\begin{aligned}
& \kappa=\frac{n_{w i} g}{2 k_{i}} \\
& C=\sqrt{\frac{n_{w i}}{\rho_{w 0}\left(K_{s}+n_{a i} K_{a}\right)}}
\end{aligned}
$$

この式 (13) を穼件に応じて解けば，厈定の解卒得る ことができるが，次に，実測值と比較するために， で述べる実験状態汶する解を求悋ておく。

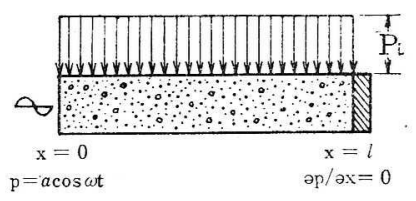

Fig. 4 Boundary Conditions in Experiments

実験の状態を模式的に表わすと, Fig. 4 のように示 される。これは, 長さ $l$ の砂層の上流端 $x=0$ の点で間 嚐水圧を正弦的 $(p=a \cos \omega t)$ に変動させ, 下流端 $x=l$ の点が閉鎖されていて $\partial p / \partial x=0$ の条件のもとで, 初期 閒隚水圧 $P_{i}$ が作用する砂層の中を, 一次元的に閒隚水 圧 $p$ が伝ぱする場合である。 $P_{i}$ は砂層の全断面を通じ て一定であるから， $n_{w i}, n_{a i}, k_{i}$ などはみな一定值とな り，P均一層中を伝ぱする。また，砂膡中を伝ぱする 閒隚水圧は，その減衰は大きいが伝ぱ速度が速いために ほとんど瞬間的に定常の状態になるから，実験值と対比 して式 (13) の妥当性を調べるためには, 定常状態にお ける解を求为比皎すれば十分である。以上の条件のもと における 1 次元での式 (13) の周期的な解は, 複素関数 を用いて簡明に表わすと次のようになる。

$$
p=A \cos (\omega t+r)
$$

ここで,

$$
\begin{aligned}
& A=\frac{a \sqrt{\left|U^{2}\right|+\left|V^{2}\right|+2|U V| \cos (\arg V / U)}}{\cosh 2 \ln +\cos 2 \ln } \\
& r=\tan ^{-1}\left\{\frac{|U| \sin (\arg U)+|V| \sin (\arg V)}{|U| \cos (\arg U)+|V| \cos (\arg V)}\right\}
\end{aligned}
$$

$$
\begin{aligned}
& U=\cos \{n x+i m(2 l-x)\} \\
& V=\cos \{n(2 l-x)+i m x\} \\
& m=\frac{1}{C} \sqrt{\frac{-\omega^{2}+\omega \sqrt{\omega^{2}+4 \kappa^{2}}}{2}} \\
& n=\frac{1}{C} \sqrt{\frac{\omega^{2}+\omega \sqrt{\omega^{2}+4 \kappa^{2}}}{2}} \\
& \kappa=\frac{n_{w i} g}{2 k_{i}} \\
& C=\sqrt{\frac{n_{w i}}{\rho_{w 0}\left(K_{s}+n_{a i} K_{a}\right)}}
\end{aligned}
$$

なお，式中，Suffix でない $i$ は虚数単位を表わす。

\section{4. 実騟装置および方法}

\section{（1）実駼装置}

不飽和状態の砂層における間隚水圧の伝ぱの様相を調 ベるために，Fig. 5 と Fig. 6 亿示すような実験装置 を製作した。Fig. 6 の装置はその中央に試料の砂をつ め, 上流側索 Fig. 5 の加圧装置により空気圧で正弦的 に間幥水圧を加圧できるようになっている。砂層内の間 㭞水圧は微少水圧計を用いて計測し電磁オシロに記録し た。これらの一連の装置である加圧装置, 動的透水試験 器, 微少水圧計の概要を以下に示す。

a) 加圧装置と動的透水試験器

加圧装置は動的透水試験器の上流側に空気圧で正弦変 動圧力を加えるための装盢で Fig. 5 にその写真を示す。

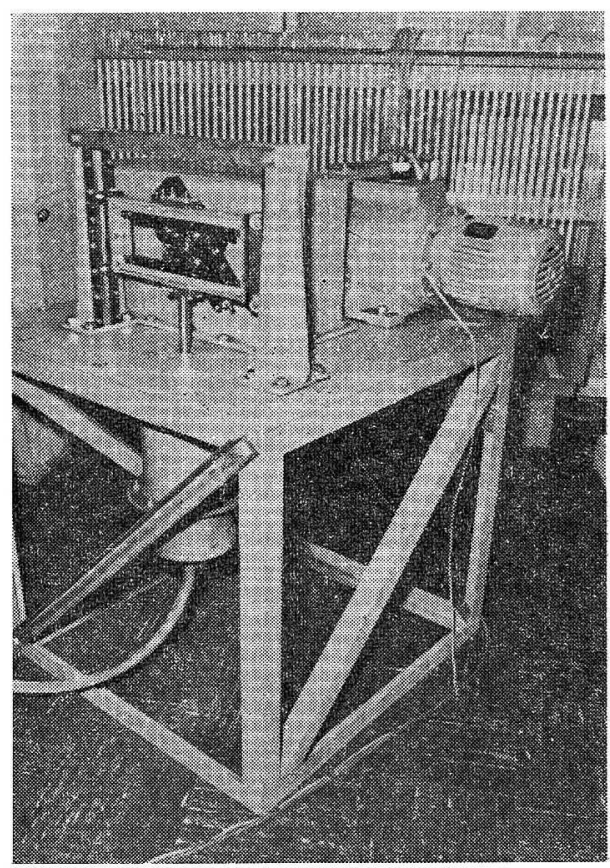

Fig. 5 Air Pressure Exciter 


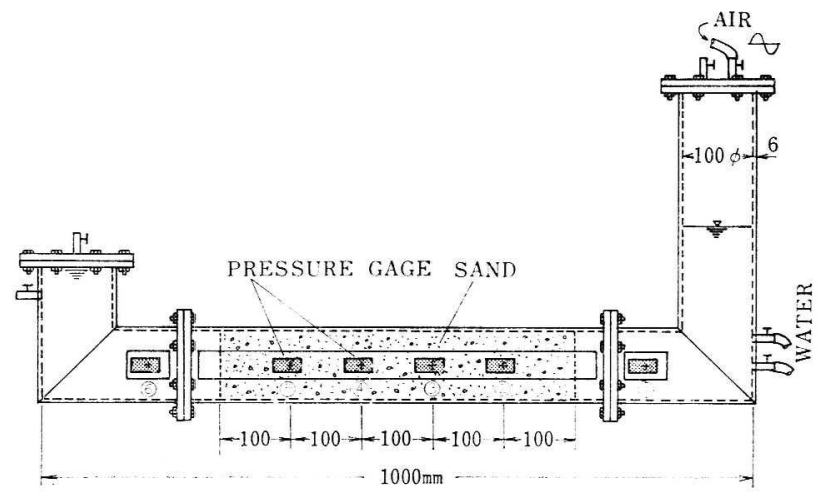

Fig. 6 Details of Dynamic Permeameter

空気圧はベロフラム式シリンダーを駆動して加えるが, 無段変速機と変速ギャ一の組合せにより $1 / 60 \sim 10 \mathrm{c} / \mathrm{s}$ の周波数で加圧できるようにし, 正確な正弦波形を作る ためにスコッチヨークを用いた。この装置で作った正 弦波形は Fig. 10 において， $x=0 \mathrm{~cm}$ と記してある波 形である $(0.7$ と $10 \mathrm{c} / \mathrm{s}) 。$

動的透水試験器は Fig. 6 亿示すように, 内径 100 $\mathrm{mm}$, 肉厚 $6 \mathrm{~mm}$ の透明アクリル管で, 砂をつめやすく するために分割できるようになっている。Fig. 6 は砂 層の長さが $50 \mathrm{~cm}$ で実験する場合の図であるが，中央 の水平管を継ぎたすことにより砂層の長さが $100 \mathrm{~cm}$ の 実験むできる。管の側面には $10 \mathrm{~cm}$ 間隔に径 $6 \mathrm{~mm}$ の 水圧取り出し孔があり, その場所に微少水圧計を取り付 け，間隚水圧が計測できるようになっている。

\section{b）微少水圧計}

物体に作用する水圧分布を計測するような場合には, 多数の水圧計を使用しなければならず，それが模型実験 のときのように微少圧力を計測する場合には高感度の水 圧計が要求される。現在高感度の水圧計のほとんどが取 りだした圧力を電気的に増幅し，記録させている。この ような方式ではピックアップ1個に 1 台の増幅器が必要 であり，測点が多くなると費用も高くなり，また計測も 非常に煩雑になってくる。このような点学考虑して製作 したのがここに述べる微少水圧計で，その外観と細部の 構造を Fig. 7 と Fig. 8 に示す。この水圧計の特長 は, 取りだした水圧を增幅しないで直接電磁オシログラ

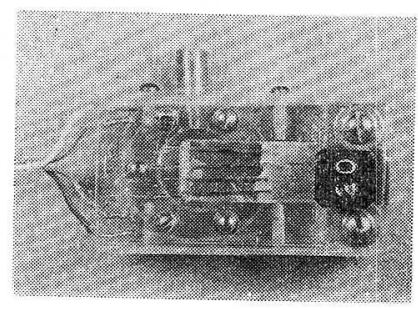

Fig. 7 Water Pressure Gage

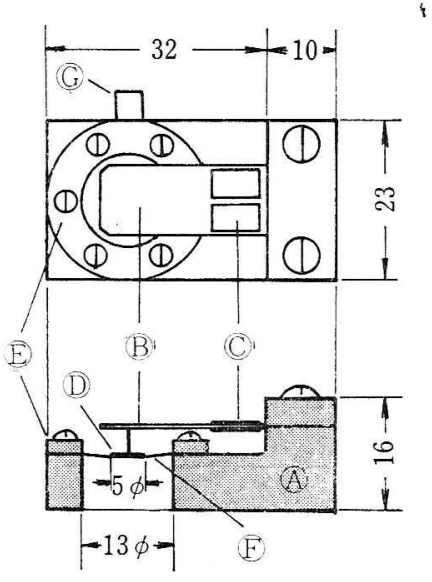

Fig. 8 Details of Water Pressure Gage

フに記録できることである。そのために受圧部の板ばね をカンチレバー (B) とし, その先端に受圧板 (D) をつけ て, 加わる力によって生じるたわみを半導体ストレーン ゲージ (C) で取りだす方式とした。使用した板ばねは長 さ $20 \mathrm{~mm}$, 幅 $10 \mathrm{~mm}$, 厚さ $0.4 \mathrm{~mm}$ のば社用りん青銅 板で, その固有振動数は $240 \mathrm{c} / \mathrm{s}$ であった。半導体ゲー ジは板ばねの表に 2 枚, 裹に 2 枚はり，4 ゲージ法を採 用し, 直流ブリッジを組み, その電源に法直流安定化電 源を用いた。受圧部の水密のためには，厚さ $0.02 \mathrm{~mm}$ のポリエチレン薄膜 (E) を使用し，受圧板の径 (d) と 受圧孔の径 $(D)$ との比 $D / d=13 \mathrm{~mm} / 5 \mathrm{~mm}$ にして直 線性のよい水圧計とした。水圧計の感度は, 電磁才シ口 グラフのガルバノメーターに $500 \mathrm{~mm} / 1 \mathrm{~mA}$ の感度のも のを使用して, 水圧 $2 \mathrm{~g} / \mathrm{cm}^{2}$ に対してスポットの振れ幅 が約 $1 \mathrm{~cm}$ を標準しした。この微少水圧計で記録した閒 隙水圧を Fig. 10 亿示す。

\section{（2）実験 方法}

a) 実 験 砂

実験に用いた砂は 2 種類でそれらを試料Ｉ上試料I と 
する。試料Iは利根川砂で $2 \mathrm{~mm}$ 以上の粒子はふるい 分けてのぞいた。試料II多摩川砂で $3 \mathrm{~mm} \sim 0.4 \mathrm{~mm}$ の粒径のものを使用した。両者の物理量を Table 1 に, 粒径加積曲線を Fig. 9 に示す。

Table 1 Characteristics of Experimental Sand-Grains

\begin{tabular}{c|c|c|c|c}
\hline Specimens & $\begin{array}{c}\text { Specific } \\
\text { Gravity }\end{array}$ & $\begin{array}{c}\text { Grain Size } \\
(\mathrm{mm})\end{array}$ & $\begin{array}{c}\text { Effective } \\
\text { Size(mm) }\end{array}$ & $\begin{array}{c}\text { Uniformity } \\
\text { Coefficient }\end{array}$ \\
\hline I & 2.77 & $2 \sim 0.08$ & 0.18 & 1.76 \\
II & 2.67 & $3 \sim 0.4$ & 0.50 & 2.30 \\
\hline
\end{tabular}

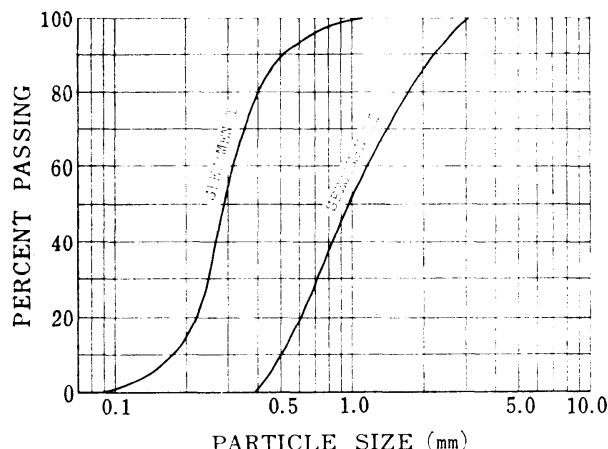

Fig. 9 Grain-Size-Accumulation Curves of Specimens

\section{b）気泡の作り方}

本実験は飽和度が高い場合を対象としているので，砂 のつめ方を変えて間隚内にできる気泡量を変化させた が，砂のつめ方は次の 2 種類であった。

A 法：試験器を鉛直に立て, 乾燥砂を沈降させてつめ, 砂の粒子に付着して一緒に沈降した気泡で不飽和 砂にする方法.

B法：試験器を鉛值に立て, 乾燥砂をつめ, 下より水を 浸透させ気泡を作り不飽和砂にする方法.

以上の方法で砂をつめることにより, 砂層内を均一に不 飽和状態にすることができたと考えられる（c）で詳 述)。

また, 気泡量の計量は動的透水試験器に砂をつめた状 態ではむずかしいので，実験に先だって気泡量の計量の ための検定を行った。検定には, 動的透水試験器 (Fig. 6 参照）の水平部分のパイプを用い，実験時と同じ方法

(A法と B法) で砂をつめ, その全体の重量を計量し， 気泡を全然含まない場合の重量上, 含む場合の重量の差 から気泡量を算定した。検定時と実験時の砂のつめ方を 同様に行えば，両者の気泡量は同じになる。Table 2 は同じ砂のつめ方で検定を 3 回行ったときの $a_{c 0}, S_{r 0}$, $k_{0(20)}$ (大気圧中での值であるために Suffix に0をつけ てある）の実測值と平均值を示した。この表が示すよう に検定值の間にはほとんどばらつきがなく一定の気泡量
Table 2 Measuring Quantity of Air Bubbles and Permeability

\begin{tabular}{|c|c|c|c|c|c|c|}
\hline Specimens & $\begin{array}{l}\mathrm{Me} \\
\text { Fill }\end{array}$ & $\begin{array}{l}\text { lods of } \\
\mathrm{g}\end{array}$ & $\begin{array}{c}n_{0} \\
(\%)\end{array}$ & $\begin{array}{c}a_{c 0} \\
(\%)\end{array}$ & $\begin{array}{l}S_{r 0} \\
(\%)\end{array}$ & $\begin{array}{l}k_{0}(20) \\
(\mathrm{cm} / \mathrm{sec})\end{array}$ \\
\hline \multirow{8}{*}{ I } & \multirow{4}{*}{ A } & & 44.5 & 6.25 & 93.8 & 0.032 \\
\hline & & & 44.9 & 6.30 & 93.7 & 0.032 \\
\hline & & & 44.7 & 6.13 & 93.8 & 0.034 \\
\hline & & Means & 44.7 & 6.23 & 93.8 & 0.033 \\
\hline & \multirow{4}{*}{ B } & & 45.0 & 10.6 & 89.4 & 0.027 \\
\hline & & & 44.6 & 9.8 & 90.2 & 0.029 \\
\hline & & & 44.9 & 10.0 & 90.0 & 0.028 \\
\hline & & Means & 44.8 & 10.1 & 89.9 & 0.028 \\
\hline \multirow{8}{*}{ II } & \multirow{4}{*}{ A } & & 38.1 & 3.10 & 96.9 & 0.187 \\
\hline & & & 37.5 & 3.49 & 96.5 & 0.216 \\
\hline & & & 38.0 & 3.00 & 97.0 & 0.234 \\
\hline & & Means & 37.9 & 3.20 & 96.8 & 0.212 \\
\hline & \multirow{4}{*}{ B } & & 37.9 & 12.6 & 87.4 & 0.173 \\
\hline & & & 37.9 & 12.7 & 87.3 & 0.164 \\
\hline & & & 37.5 & 13.0 & 87.0 & 0.146 \\
\hline & & Means & 37.8 & 12.8 & 87.2 & 0.161 \\
\hline
\end{tabular}

で砂をつめることができるので, 実験のときの気泡量と してはこの平均值をもとにした。また，実験において砂 層内に水を流したり，変動圧力を加えたりすることによ り, 気泡が移動し気泡量が变化するのではないかとの疑 問も生じる。しかし，これは次のような実験を行うこと により, 気泡量の変化はないことがわかった。この実験 は, 第一回の実験で, 砂層内に水を流したり, 変動圧力 を加えたりして所定の実験を終了した後, 一昼夜放置し て, まったく同じ状態で第二回の実験を行い，その実測 值を比較した。その結果, 両者の透水係数や変動間隙水 圧の実測值は全然変化がなかった。以上のような実験の 結果からも，2. (1) a) で述べたように, 気泡は砂粒子 にしっかりと付着していて，水の流動に応じて移動しな いという仮定の正しいこともわかる。

一方, 砂層内にできた気泡の大きさは, 透明な試験器 を通して砂層の表面を注意して見ると, 肉眼で見える気 泡が無数に観察できる。一定面積内でその気泡がしめる 面積比と実測した気泡含有率とを対比すると, 砂層内の 気泡はほとんど肉眼で見える程度の気泡で構成されてい ることがわかるので, Fig. 2 の結果から考えても，こ の実験注ける気泡に対しては，表面張力の影響は無視 できるものと考えられる。

c) 実験方法

動的透水試験器に砂をつめる方法は, 試験器の上流測 の鉛直部分のパイプ (Fig. 6 の右側) を取りはずし, 下流側を下にして固定枠ごと鉛直に立て，その上端に漏 斗をすえ, 所定の間隚率になるように, 試験器に振動を あたえながら連続して砂を投入した。砂層骨格の圧縮率 を調べるために行った完全飽和状態の実験では, 煮沸し 
Table 3 Data Pertaining to Tests of Saturated Sand

\begin{tabular}{c|c|c|c|c|c|c|c|c}
\hline Specimens & $\begin{array}{c}\text { Test } \\
\text { No. }\end{array}$ & $\begin{array}{c}T \\
(\mathrm{C})\end{array}$ & $\begin{array}{c}n_{i} \\
(\%)\end{array}$ & $\begin{array}{c}S_{r i} \\
(\%)\end{array}$ & $\begin{array}{c}k_{i} \\
(\mathrm{~cm} / \mathrm{sec})\end{array}$ & $\begin{array}{c}l \\
(\mathrm{~cm})\end{array}$ & $\begin{array}{c}f a \\
(\mathbf{c} / \mathbf{s})\end{array}$ & $\begin{array}{c}2 a \\
\left(\mathbf{g} / \mathrm{cm}^{2}\right)\end{array}$ \\
\hline \multirow{2}{*}{$\mathrm{I}$} & 79 & 13 & 44.0 & 100 & 0.035 & 50 & $1 \sim 11$ & 10 \\
& 80 & 12 & 42.0 & 100 & 0.027 & 50 & $1 \sim 11$ & 10 \\
\hline \multirow{2}{*}{ II } & 81 & 13 & 37.8 & 100 & 0.294 & 50 & $1 \sim 11$ & 10 \\
& 82 & 10 & 35.6 & 100 & 0.198 & 50 & $1 \sim 11$ & 10 \\
\hline
\end{tabular}

Table 4 Data Pertaining to Tests of UnsaturatedeSand

\begin{tabular}{|c|c|c|c|c|c|c|c|c|c|c|c|c|}
\hline Specimens & $\begin{array}{l}\text { Methods of } \\
\text { Filling }\end{array}$ & $\begin{array}{l}\text { Test } \\
\text { No. }\end{array}$ & $\underset{\left({ }^{\circ} \mathrm{C}\right)}{T}$ & $\begin{array}{c}n_{i} \\
(\%)\end{array}$ & $\begin{array}{c}n_{a i} \\
(\%)\end{array}$ & $\begin{array}{l}n_{w i} \\
(\%)\end{array}$ & $\begin{array}{c}a_{c i} \\
(\%)\end{array}$ & $\underset{(\%)}{S_{r i}}$ & $\begin{array}{c}k_{i} \\
(\mathrm{~cm} / \mathrm{sec})\end{array}$ & $\begin{array}{c}l \\
(\mathrm{~cm})\end{array}$ & $\underset{(c / s)}{f}$ & $\begin{array}{c}2 a \\
\left(\mathrm{~g} / \mathrm{cm}^{2}\right)\end{array}$ \\
\hline \multirow{7}{*}{ I } & \multirow{5}{*}{ A } & 55 & 22 & 41.0 & 2.95 & 38.05 & 7.21 & 92.8 & 0.022 & 50 & $0.1 \sim 10$ & 10 \\
\hline & & 57 & 22 & 42.0 & 2.88 & 39.12 & 6.87 & 93.1 & 0.026 & 50 & $0.1 \sim 10$ & 10 \\
\hline & & 53 & 23 & 43.0 & 2.82 & 40.18 & 6.55 & 93.5 & 0.030 & 50 & $0.1 \sim 10$ & 10 \\
\hline & & 59 & 23 & 43.9 & 2.76 & 41.14 & 6.29 & 93.7 & 0.034 & 50 & $0.1 \sim 10$ & 10 \\
\hline & & 61 & 22 & 44.9 & 2.70 & 42.20 & 6.10 & 93.9 & 0.038 & 50 & $0.1 \sim 10$ & 10 \\
\hline & \multirow{2}{*}{ B } & 63 & 23 & 44.9 & 4.42 & 40.48 & 9.84 & 90.2 & 0.029 & 50 & $0.1 \sim 10$ & 10 \\
\hline & & 37 & 21 & 45.3 & 4.42 & 40.88 & 9.76 & 90.2 & 0.029 & 100 & $0.03 \sim 2$ & 15 \\
\hline \multirow{4}{*}{ II } & \multirow{2}{*}{ A } & 49 & 22 & 37.0 & 1.20 & 35.80 & 3.24 & 96.8 & 0.306 & 100 & $1 \sim 10$ & 15 \\
\hline & & 51 & 22 & 37.6 & 1.18 & 36.42 & 3.14 & 96.9 & 0.334 & 100 & $1 \sim 10$ & 15 \\
\hline & \multirow[t]{2}{*}{ B } & 43 & 22 & 38.1 & 4.73 & 33.37 & 12.4 & 87.6 & 0.219 & 100 & $0.1 \sim 8$ & 15 \\
\hline & & 47 & 23 & 37.8 & 4.73 & 33.07 & 12.5 & 87.5 & 0.190 & 100 & $0.1 \sim 7$ & 15 \\
\hline
\end{tabular}

$T:$ Temperature of Water

$l$ : Length of Sample $f$ : Frequency of Forced Oscillating Pressure

$a$ : Amplitude of Forced Oscillating Pressure
て気泡をとりのぞいた砂を外気にふれないようにし，水 と一緒に沈降させてつめた。不飽和状態の実験で, A法 において注砂の沈降水深を一定に保ちながら乾燥砂を投 入した。また B 法では, 先に試験器内に乾燥砂在所定の 間隚率でつめておき, その後, 試験器の下方より一定の 水圧で水を浸透させた。

以上の方法で試験器に砂をつめた後, 試験器の上流側 の鉛直パイプを取り付け，砂が外気にふれないように試 験器を水平にし, 実験を行った。

実験の手順泫，まず，上流側の水位を水圧計の位置よ り約 $20 \mathrm{~cm}$ に保ち，その水面を加圧装置により空気圧 で正弦的汇加圧し，砂層内の間隌水圧の変動を微少水圧 計で計測した。実験の終了後には, 試騃器の下流側のふ たをはずし，透水試験を行い透水係数を実測した。

Table 3 には完全飽和状態における実験の種類を示 し, Table 4 に不飽和状態における実験の種類を示し た。不飽和状態の実験の気泡量は, 前述の気泡量検定の ときの平均值をもとにした。砂のつめ方が $\mathrm{A}$ 法の場合に は気泡は砂の粒子に付着して沈降しているので, 間隚率 によって気泡量は異なるために，実験時の 気泡含有率 は, $n_{a i}=n_{a 0} \times n_{0} / n_{i} \quad\left(n_{a 0}\right.$ と $n_{0}$ 㰸定時の気泡含有率 と間隚率， $n_{i}$ は実験時の閒嚐率）として算定した。砂 のつめ方が B法の場合には，検定時，実験時いずれの場 合も，試料 Iでは間隚率が $45 \%$, 試料IIでは $38 \%$ に つめたので間隚率による補正は行わなかった。また，実 験時には，試験器上流側の水位を水圧計の位置より 約
$20 \mathrm{~cm}$ 高くした状態で変動圧力を加えたので，初期間隚 水压 $P_{i}$ は $1033.6+20=1053.6 \mathrm{~g} / \mathrm{cm}^{2}$ となり, 大気 圧中で行った検定時上りも実験時には $20 \mathrm{~g} / \mathrm{cm}^{2}$ だけ圧 力が高くなっているため, ヘンリ一の法則を用い，わず かな量ではあるがA法，B法いずれの場合も補正を行い 実験時の気泡量とした。

また，透水係数 $k_{i}$ は飽和，不飽和いずれの場合も動 的実験と同じ状態で，実験の直後に計測した值であり， 前述の気泡量と同様に, 式 (14) を用いて計算する場合 には Table 3, 4 の值を用いた。l 法層の長さである が， $l=50 \mathrm{~cm}$ の実験のときには，加える正弦変動圧力 の全振幅 $2 a$ を $10 \mathrm{~g} / \mathrm{cm}^{2}$ とし， $l=100 \mathrm{~cm}$ のときには $15 \mathrm{~g} / \mathrm{cm}^{2}$ とした。また周波数は最低 $f=0.03 \mathrm{c} / \mathrm{s}$ から 最高 $10 \mathrm{c} / \mathrm{s}$ の範囲で実験を行った。

Fig. 10 は間偿水圧を微少水圧計で計測した記録例で ある。 $x=0 \mathrm{~cm}$ としるしてある波形は加圧力で, Fig. 6 の(1)の水圧計で計測したものである。 $x=10 \sim 40 \mathrm{~cm}$ は 砂層内の間嚐水圧で (2) (5) の水圧計で, $x=50 \mathrm{~cm}$ は 砂層の下流端の間隚水圧として (6)の水圧計でそれぞれ計 測した波形を示す。

\section{5. 実験值と計算値の比較および考察}

\section{（1）完全飽和状態の場合}

式（14）を用い間隚水圧を計算するにあたり，砂層骨 


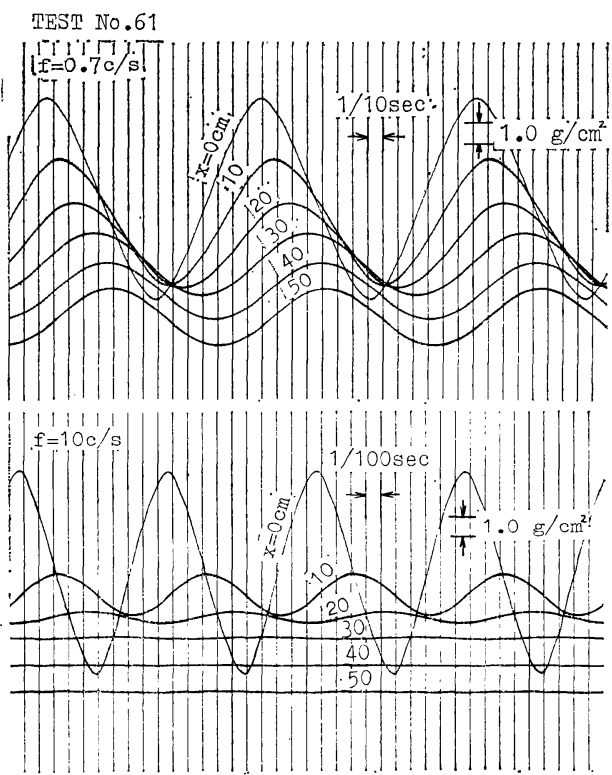

Fig. 10 Oscillograms of Pore Water Pressure

格の圧縮率 $K_{s}$ を知る必要がある。完全飽和状態での 間嚐水圧は, 式 (14) の $C$ の式を $C=\sqrt{n_{i} / \rho_{w_{0}} K_{s}}$ と おき計算できるから，もし，Ks $K_{s}$ が定数であるならば実 験值をむとに $K_{s}$ を逆算することができる。Fig. 11 は完全飽和の状態で，上記の実験方法により砂層の上流 端を正弦的に加圧した場合, その加圧力に対する砂層内 の各点における間隙水圧の減衰率を周波数に応じて図示 したもので， $x$ は砂層の上流端からの距離 $(\mathrm{cm})$ であ

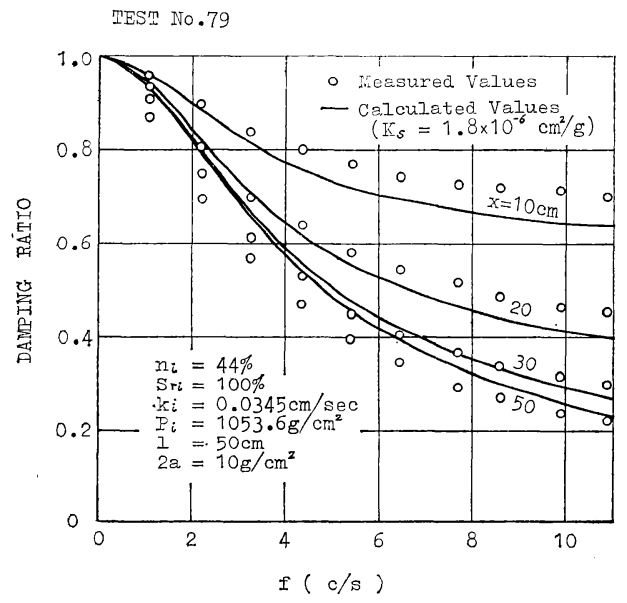

Fig. 11 Damping Ratio of Pore Water Pressure in Saturated Sand

(Test No. 79)
る。式 (14) で減衰率を計算する場合には， $a=1$ とお いたAの式を計算すればよいが，Fig. 11 の実線は実 測值（丸印）の平均值となるような $K_{s}$ で計算した減 衰率である。

この図でわかるように， $K_{s}$ を定数とした計算值は実 測值と一致せず, 正確には $K_{s}$ を定数としてとりあつ からことはできない。しかし，実測值の平均值となる $K_{s}$ の值は $1.8 \times 10^{-6} \mathrm{~cm}^{2} / \mathrm{g}$ で，この值は砂層骨格の 圧縮率として一般に用いられている值とだいたい一致し ている。

この研究は, 間偿内に存在する気泡の圧縮性による間 偿水圧の伝ぱを中心にするものであり, 砂層骨格の圧縮 率による非線型的な間嚐水圧の伝ぱについては考察しな い。しかし， $K_{s}$ を定数とした式 (14) の $C$ の式で, $K_{s}=1.8 \times 10^{-6} \mathrm{~cm}^{2} / \mathrm{g}$ を用いた場合, $n_{a i} K_{a}$ と $K_{s}$. の比, すなわち $n_{a i} K_{a} / K_{s}$ の值は, 試料工の砂で気泡, 量が最も少ない場合でも 14 倍となる。そのために, 不 飽和状態における実測值に対して, 砂層骨格の圧縮率に よっておこる非線型性は，ほとんど影響をおよぼさな ฟ。

以上のような理由で，不飽和状態の計算で，試料 I の砂では砂層骨格の圧縮率として $K_{s}=1.8 \times 10^{-6} \mathrm{~cm}^{2} / \mathrm{g}$ の值を用いた。また, 試料 II の砂についても同様に実: 験を行った結果， $K_{s}=2.0 \times 10^{-6} \mathrm{~cm}^{2} / \mathrm{g}$ となった。

\section{（2）不飽和状態の場合}

Fig. 12 から Fig. 15 に不飽和状態における実験值 と計算值を比較して数例を示した。図には Test No. を 示してあるので，実験の状態は Table 4 を見れば一目 瞭然である。計算值は式（14）を計算して求めたが，式 に入る気泡含有率 $n_{a i}$ や透水係数 $k_{i}$ は実験のさいに 求めた值 (Table 4 参照) を用いた。また， $K_{s}$ は試料 I の砂では $1.8 \times 10^{-6} \mathrm{~cm}^{2} / \mathrm{g}$, 試料 II の砂では $2.0 \times$ $10^{-6} \mathrm{~cm}^{2} / \mathrm{g}$ (5. (1) 参照) とし, 気泡の圧縮率は $K_{a}$ $=1 / P_{i}=1 /(1033.6+20)=1 / 1053.6 \mathrm{~cm}^{2} / \mathrm{g} \quad$ (3. および 4. (2) c) 参照) とし計算した。

Fig. 12 は試料 I の砂で, 減衰率と位相差を加圧力 の周波数に応じて示したもので, 丸印は実測值，実線は 計算值である。 $x$ は砂層上流端からの距離を示す。減衰 率は正弦的加圧力の振幅と, 加圧力に応じて砂層内で変 動する間隊水圧の振幅との比であり, 計算值は, 式(14) で $a=1$ とおいた A の式を計算したものである。位相 差は加圧力に対する砂層内の各点の位相のずれを示すむ ので，計算值は式 (14) のrの式を計算したものであ. る。Fig. 12 は周波数の小さい範囲を明確にするために 半対数グラフにプロットした。

Fig. 13 は試料 II の砂に扔ける減衰率と位相差で, 
TEST NO .55
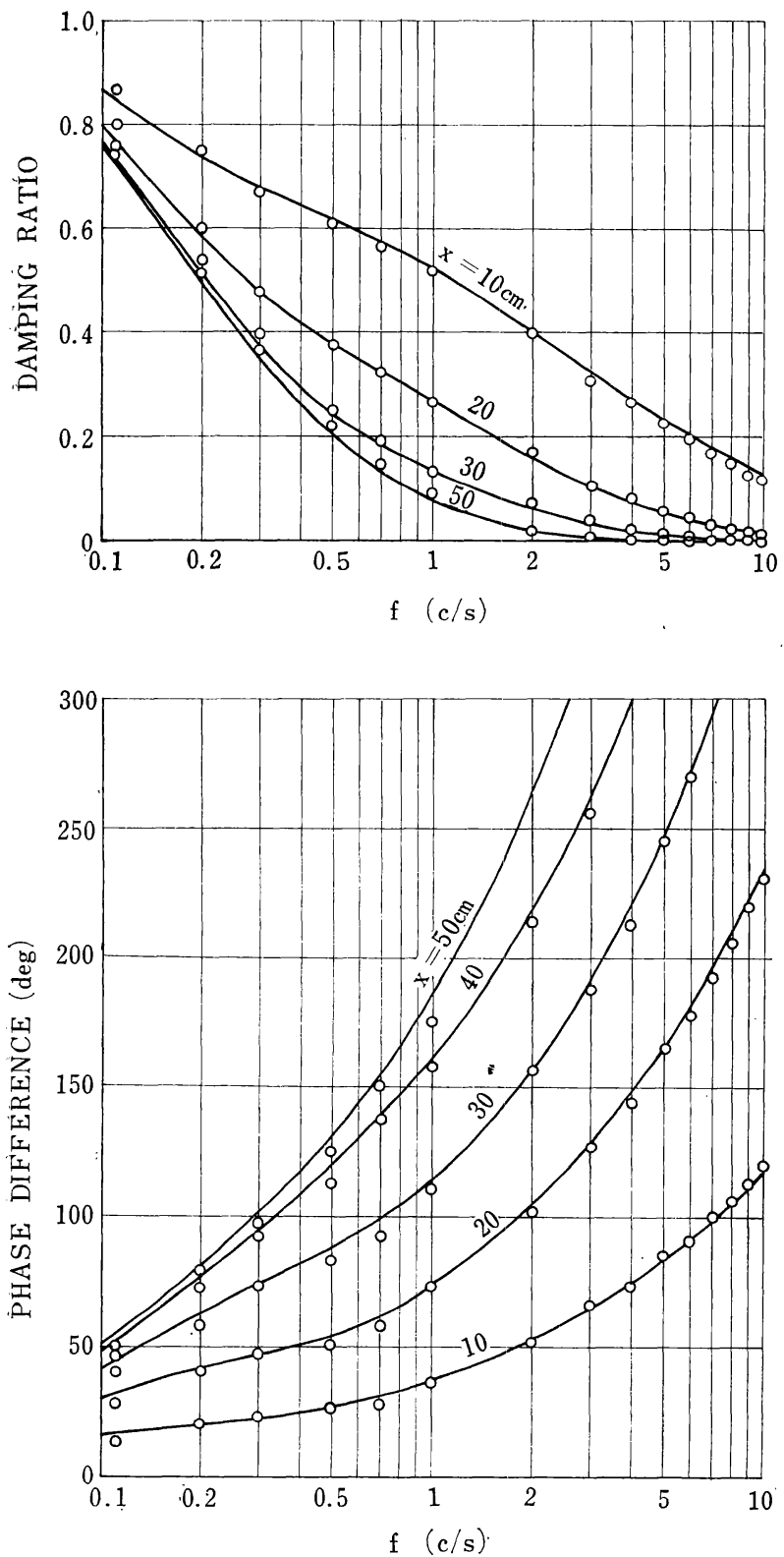

— ; CALCULATED VALUES

Fig. 12 Damping Ratio and Phase Difference of Pore Water Pressure in Unsaturated Sand (Test No. 55)

砂層の長さ $l=100 \mathrm{~cm}$ である。この例では， $n_{a i} K_{a} / K_{s}$ の值は約 6 倍であるから， $K_{s}$ による非線型性の影響が 幾分でているように思われる。

Fig. 14, 15 は加圧中における砂層内の間吵水圧の分 布を示したものである。 $P$ は水圧計に作用する水圧で,
TEST No.51
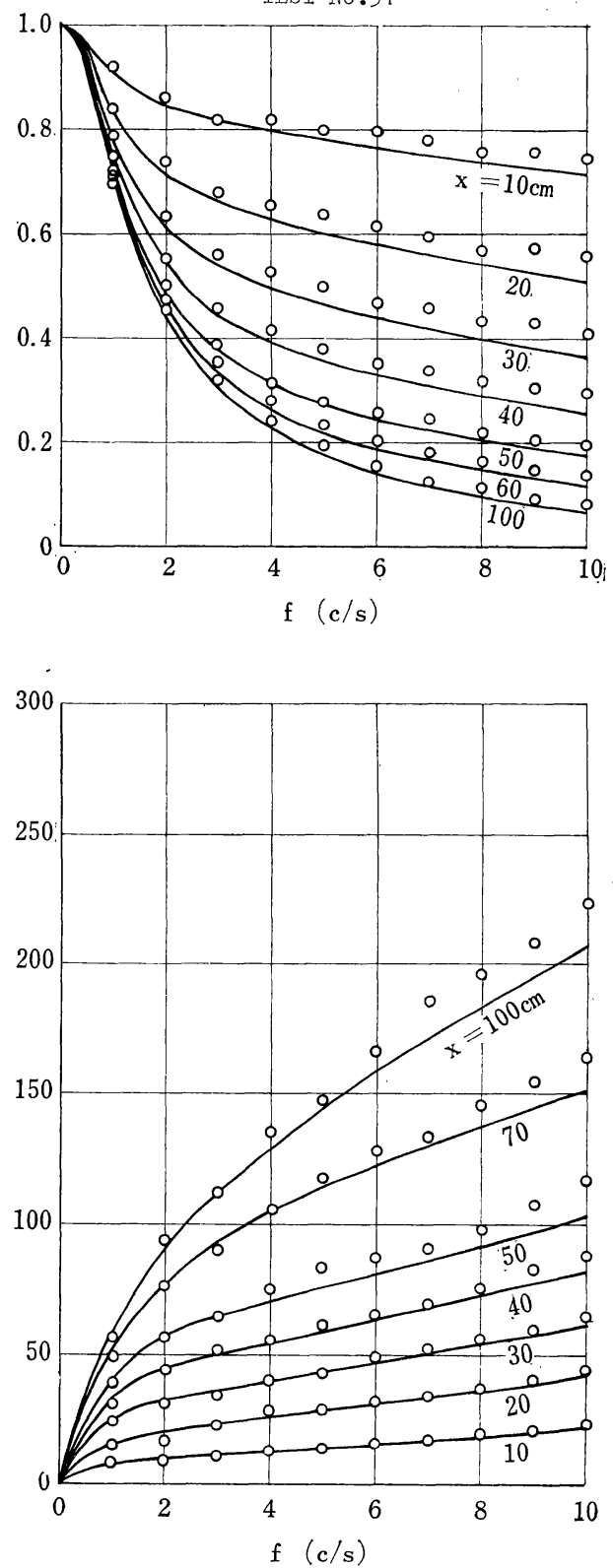

○; MEASURED VALUES

Fig. 13 Damping Ratio and Phase Difference of Pore Water Pressure in Unsaturated Sand (Test No. 51)
初期水圧 $p_{0}\left(20 \mathrm{~g} / \mathrm{cm}^{2}\right)$ と変動間隚水圧 $p$ との和 $(P=$ $\left.p_{0}+p\right)$ である。丸印, 三角印および四角印は実測值で, 実線，鎖線および一点鎖線注計算值である。丸印および 実線は加圧力 $(p=a \cos \omega t)$ が最大值 $(\omega t=0)$ になっ た瞬間における砂層内の間隚水圧の分布を示し, 三角印 

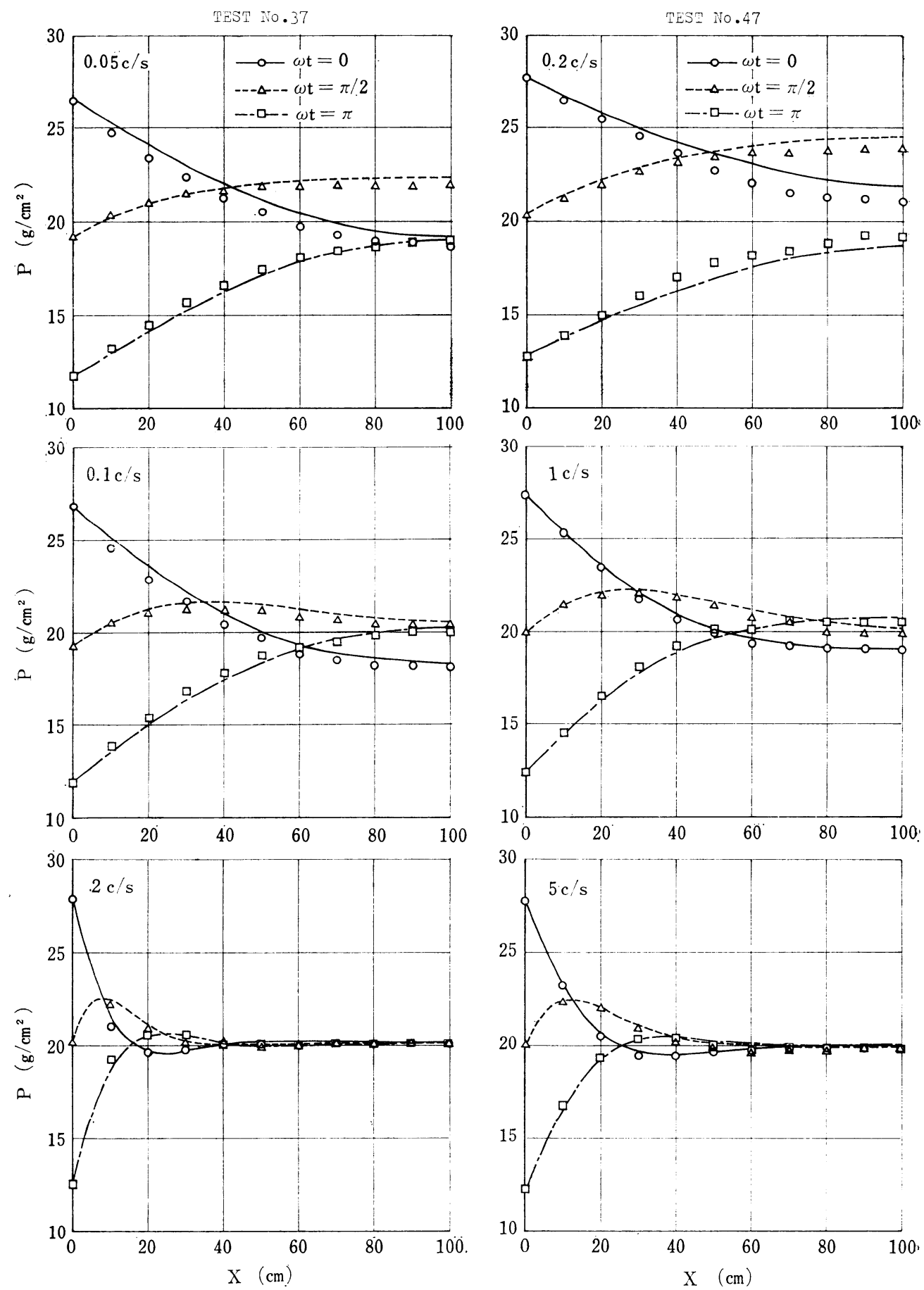

ב-ב- CALCULATED VALUES

$\circ \triangle \mathrm{Q} ;$ MEASURED VALUES

Fig. 14 Distribution of Pore Water Pressure (Test No. 37)
Fig. 15 Distribution of Pore Water Pressure (Test No. 47) 
と鎖線および四角印と一点鎖線はそれぞれ $\omega t=\pi / 2, \pi$ (最小値)になった瞬閐の分布である。またこれらの 図で $x=0$ における丸印と四角印の間隔は加圧力の全 振幅 (2a) を示している。計算值は, 式 (14) の $p$ を 各 $\omega t$ に応じて計算し， $p_{0}$ に加えた值であるが，計算 に必要な $n_{a i}, k_{i}$ などつ值は実験時におう沙る Table 4 の值を用いた。Fig. 14 は試料 I の砂で, Fig. 15 は 試料 II の砂であり, 両者の気泡量はほぼ同じである が，I の透水係数は II のそれと比較して $1 / 10$ 程度で あるために，II にくらべ間隚水圧の減單度合は大き w。

以上の図で，実測值上計算值がよく一致することか ら, 飽和度が $90 \%$ 前後の砂層において, 変動間隚水圧 $p$ （ゲージ圧力）が初期間偿水圧 $P_{i}$ （絶対圧力）に比 べ小さい場合には, 間嚐水圧の伝ぱに関する式は, 式 (13) で示される線型方程式で十分であるといえる。し かし，気泡量宓非常に少なくなってくると，間隙水圧の 挙動は気泡の圧縮性よりも砂層骨格の圧縮性からの影響 が大きくなり，式（13）で示したような線型方程式で正 確にあらわすことができなくなる。一方，気泡量が多く なると有効間隚率や透水係数は間隚水圧の変動に対して 変化が大きくなり，これらを $p$ の関数とした非線型方 程式でないと現象を適確にあらわすことができない。ま た, $p$ が大きく変動する間隚水圧の場合には, 気泡の 圧縮率は式 (7) で示されるように $P$ の関数となり, 当然非線型の現象となる。しかし，これらはあくまでも 精度上の問題で，ある程度の誤差を許すなら柋，式(13) の線型方程式はかなりの䉇囲に適用できるものと思われ る。

\section{6. むす び}

以上述べてきたように，この論文では飽和度が高い砂 層に, 初期間幥水圧（絶対圧力）に比較して小さい周期 的変動水圧（ゲージ圧力）が作用した場合の間隚水圧の 伝ぱについて考察を行い，式（13）で示寸線型方程式で 十分に現象を表現することができた。しかし，この式で 正確に表わすことができるのは上述のように限られた 範国であり，不飽和砂層における間隚水圧の挙動に対し て，より広、範囲に適用できる式は複雑な式となるであ ろう。これらについては本文中で一応考察を行ったが,
ここでまとめてみると,次のような状態について考慮し， 式をたてなければならない。(1) 大きい变動水圧が作用 した場合一気泡の圧縮率や透水係数は最も塑純に考え ても，式 (7) や式 (10) で示すように変動間幥水圧の 関数としてあらわさなければならない。（2) 飽和度が低 い場合一透水係数に詨する变動間隚水圧の影響がより強 くなると同時に, 式 (8) で示すような 飽和状態に準じ た考え方も適用できなくなってくる。（3) 飽和度が非常 に高い場合一飽和状態に近くなると 5.（1）で述べた ように砂層骨格の圧縮率による非線型性を考慮しなけれ ばならない。(4) 変動間隚水圧の周期が長い場合一間隚 水圧の変動に応じて, 水中に対する気泡の溶解, 放出に よる気泡量の時間的变化を考える必要がある。(5) 気泡 の径が非常に小さい場合一表面張力の影響を無視できな くなる。

このような状態を教慮し式をたてるならば，より広い 範囲の不飽和砂層に適用できるであろう。しかし奏際の 地層の不均一性などを考えると，いたずらに複雑な式を 求めるよりも，許される精度で簡明な式を用い現象を表 現することが先決だと思われる。

最後にこの研究を指導して下さった船舶技術研究所の 故丹羽室長と貴重なご助言をいただいた名古屋大学の市 原教授に感謝いたします。

なお，本報告における計算は船舶技術研究所共用電子 計算機 FACOM 270-20を用いて行った。

\section{参考 文 献}

1) Schuurman, $I_{R}$.E.: The Compressibility of an Air/ Water Mixture and a Theoretical Relation between the Air and Water Pressures, Geotechnique, Vol. 16, No. 4, pp. 269 281, 1966.

2) Kenneth L. Lee and David K. Black: Time to Dissolve Air Bubble in Drain Line, Proc. of ASCE, Vol. 98, No. SM 2, pp. 181 194, 1972.

3) David K. Black and Kenneth L. Lee: Saturating Laboratory Samples by Back Pressure, Proc. of ASCE, Vol. 99, No. SM 1, pp. 75 93, 1973.

4) 大草重康：海岸に少ける地下水運動の特異な例, 第 13 回 土質工学シンポジウム発表論文集, pp. 17〜23, 1968.

5）石原藤次郎·本間 仁編：応用水理学 中 II, pp. 309 337, 丸善, 1968.

6) 本間 仁·安芸㬵一編: 水理学, pp. 534 535, 岩波書 店, 1962 .

7）土木学会編：土木工学ハンドブック, pp. 299, 技報堂, 1964.

(1973. 4. $14 \cdot$ 受付) 